\title{
A Study of Vocational Students Perception during Apprenticeship in Insurance Industry
}

\author{
Karin Amelia Safitri ${ }^{1, a)}$ \\ ${ }^{1}$ Universitas Indonesia \\ a)karinka1803@gmail.com
}

\begin{abstract}
Vocational Higher Education is an formal college providing knowledge as well as preparing the students for six months apprenticeship after five semesters school. This study is based upon work that the researcher has done to investigate the contribution of this institution especially insurance administration and actuary seen from student's perspective for apprenticeship to develop their skill. This study used qualitative data which were collected by interviewing the randomly chosen apprentices and are measured with the questionner. The study shows that $58,5 \%$ from total apprentices had difficulty when they are doing their job which be caused by what they had to do is a little bit different with theory taught in college. But they think the lecturers had an important role in a learning and gave them many theories before they went to the apprenticeship. The finding revealed that they prefered to learn by watching others working. They watched, learnt, and did the job.
\end{abstract}

Keywords: apprenticeship, insurance, student's perception, vocational education

\begin{abstract}
Abstrak. Pendidikan Tinggi Kejuruan adalah perguruan tinggi formal yang menyediakan pengetahuan serta mempersiapkan siswa untuk magang enam bulan setelah sekolah lima semester. Penelitian ini didasarkan pada pekerjaan yang telah peneliti lakukan untuk menyelidiki kontribusi lembaga ini terutama administrasi asuransi dan aktuaris dilihat dari perspektif siswa untuk magang untuk mengembangkan keterampilan mereka. Penelitian ini menggunakan data kualitatif yang dikumpulkan dengan mewawancarai peserta magang yang dipilih secara acak dan diukur dengan kuesioner. Studi ini menunjukkan bahwa 58,5\% dari total peserta magang mengalami kesulitan ketika mereka melakukan pekerjaan mereka yang disebabkan oleh apa yang harus mereka lakukan sedikit berbeda dengan teori yang diajarkan di perguruan tinggi. Tetapi mereka berpikir dosen memiliki peran penting dalam pembelajaran dan memberi mereka banyak teori sebelum mereka pergi magang. Temuan itu mengungkapkan bahwa mereka lebih suka belajar dengan melihat orang lain bekerja. Mereka menyaksikan, belajar, dan melakukan pekerjaan.
\end{abstract}

Kata kunci: magang, asuransi, persepsi mahasiswa, pendidikan vokasi 


\section{INTRODUCTION}

Association of Southeast Asia Nations (ASEAN) economic society creates a unified market and production base that will eliminate restrictions on goods, services, capital and labor / human resources or professionals among countries. As such, ASEAN member countries are challenged to compete closely with each other. Governments of each country should be aware of the conditions of the free market in order to continue to develop the ability to follow the competition in any field. Because of that, the government of Indonesia is improving the competence of human resources according to the needs of the industrial world today, it launched several vocational education programs in several areas. The vocational higher education in Indonesia is an education that prepares students to work in certain industry and supports the mastery of certain applied skills, usually consist of diploma education programs (diploma 3 and diploma 4 which is equivalent to the academic program of strata 1). The development of vocational higher education in Indonesia is based on the projection of a long-term demand market driven, inovation, educational needs and mastery of certain competency required by the world of work at a national level. Anticipation efforts produce information about the types of skills and skilled people required in the future world of work and the ways in which this demand can be met through education and apprenticeship provision. The vocational education program prepares a specialized curriculum, in contrast to the curriculum in the strata one program, the science provided in more contextual vocational education or knowledge theories must be linked to real life. Hiim (2017) argues that from a pragmatic epistemological perspective, it can be said that vocational knowledge is contextual and holistic, and comprises a complex physical whole, motor skills, intellectual understanding, values, and divinized concepts. To ensure the relevance of the curriculum, the curriculum is required where authentic practice work is basic, and the subject is integrated with the practical work experience of the student.

The International Labour Office (ILO) 1939 defined the expression apprenticeship means any system by which an employer undertakes by contract to employ a young person and to train him [or her] or have him [or her] trained systematically for a trade for a period the duration of which has been fixed in advance and in the course of which the apprentice is bound to work in the employer's service. Apprenticeship training is a work-based form in Industry depends on a written fixed-term employment contract (apprenticeship contract) between an employer and an apprentice. Approximately 70-80 percent of apprenticeship training takes place in the workplace, where the apprentice's training is entrusted to the responsible workplace instructor. Workplace training is supplemented with theoretical studies, which are mainly provided by vocational institutions.

The apprenticeship on Vocational Higher Education in Indonesia comprises 3 years. The apprentices spend approximately 5 months of each year learning in the formal context of the college and the remaining year learning in the informal context of the workplace while each place has its own policy in determining how long an internship takes. In Germany, apprentices will in turn make training contracts with companies during training and they will not be considered as interns, but company members during their training (usually 3 years) (Gessler \& Howe, 2015). Chan (2013) stated by giving various identification of progressive work methods by other people, before accepting the actual students themselves for each job given, is an important result of forming the identity of the work through apprenticeship. In the apprenticeship process students will learn to observe every work done by their supervisor before they do it themselves. As we know that observing is very important like Chan (2015) stated in trade-based workplaces, observation by observation is important because of the work environment and the nature of work. 
Some relevant literatures revealed that learners know clearly what the curriculum is, and it organises the outlines of their everyday practice (Lave, 1990, p. 315). The ability to learn by observing physical tasks (i.e. the intra-psychological) as modelled and guided by practitioners (i.e. the inter-psychological) is proposed by Billett (2001), and another study showed the result has been the formulation of a set of learning theories applicable to informal settings: e.g. cognitive apprenticeship (Collins et al, 1989).

Apprentices is obligated to be active in the workplace which this statement is supported by First, if feedback is simply supplied by another person (e.g. a supervisor), it is less effective than if the recipient takes a more active role, through shared dialogue and analysis (Ilgen et al, 1979; Ashford \& Cummings, 1983; De Gregorio \& Fisher, 1988; Brinko, 1990). Secondly, feedback is better if it is informative, providing increments in knowledge, rather than simply a statement of whether correct or incorrect (Ilgen et al, 1979). The objectives of This study is to explore the contribution of Insurance Administration and Actuary Study Program, Vocational Higher Education University of Indonesia for apprentices learning in workplace.

\section{MATERIALS AND METHODS}

This article draws on a study of apprenticeship learning experiences in Vocational Higher Education Program, University of Indonesia with 62 respondents which are apprentices from Insurance Administration and Actuary study program of this institution. This sample of apprentices was chosen randomly with simple random sampling method. The mean age of apprentices is 21 years, in which the minimum age is 20 years and the maximum one is 22 years. This study is a descriptive-qualitative research. The objective is to try to describe, explore and comprehend the contribution of vocational education especially insurance administration and actuary for apprentices' learning experiences through their perspectives. This research methodology begins with the Researcher forming an approach to the investigation and seeking to understand the respondents experiences.

The qualitative data is an interview process which was conducted as a conversation between researcher and respondents. The guiding questions were used as conversation starters, with participants encouraged to tell how they learnt at the apprenticeship, what influences had assisted the processes of learning or practising skills and the contributions of others in the workplace to their learning. In addition to interviews, researcher also collected data by distributing questionnaires as the quantitative data. Apprentices were interviewed either face-to-face or by telephone.

\section{RESULTS AND DISCUSSION}

The qualitative data was collected within Insurance Administration and Actuary Study Program, Vocational Higher Education University of Indonesia which measured the apprentices perceptions on how much the influence during the college as formal learning toward their apprenticeship. The apprentices are the students of 2014 class. The percentage of female students who filled the questionners is $69 \%$ and the percentage of male students is $31 \%$. As a basic information, students apprenticeship through his apprenticeships in insurance companies in several divisions namely: claims, underwriting, marketing, policy, and actuarial. There is a pie chart which showed the insurance division as follow. 


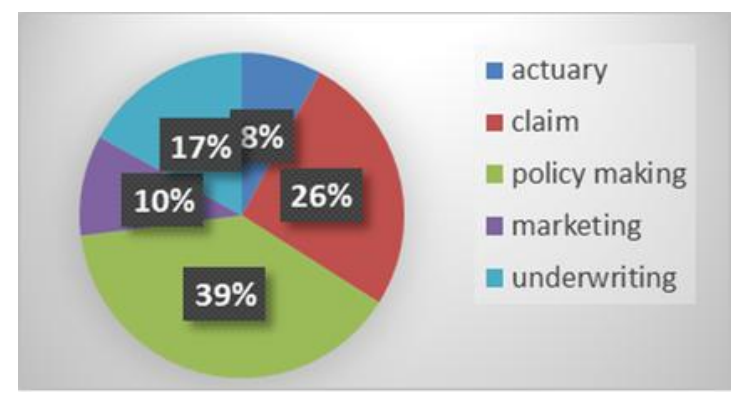

Figure 1. The Percentage of the Apprentices Respondents Based on Their Division

The policy making is where the most apprentices is working at by the insurance human resource development manager. Before they were apprenticing, they were interviewed and asked by some managers related to their interest and competencies. The process of making an insurance policy begins with the creation of a life / loss insurance request. The first is the recording of prospective customer data. In filling the application letter of insurance must include the utmost good faith of the customer so that the data provided is true.

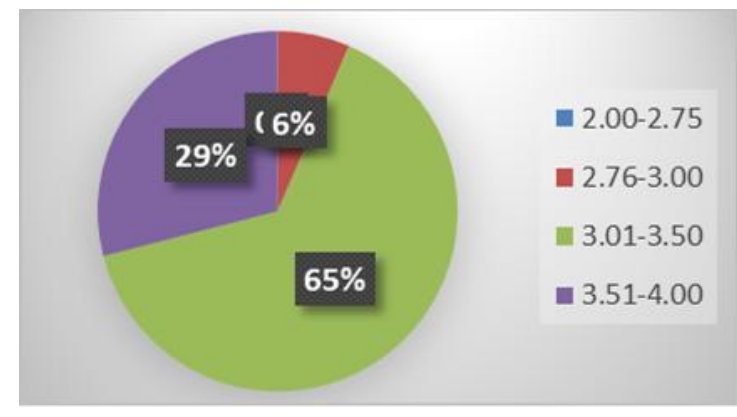

Figure 2. The percentage of Apprentices Respondents Based on Their GPAs

In the curriculum applied this study program refers to ministry of research and technology of higher education Indonesia (KEMENRISTEDIKTI) no 44 of 2015 on National Standards of Higher Education that emphasizes the learning process that emphasizes the learning process that emphasizes the activities of lectures and lab work. A total of 44 credits or $40 \%$ theory-based and as many as 66 credits or $60 \%$ used for practicum. Based on the number of learning hours, students of Life Insurance study program will complete their study by taking 3355 hours of learning equivalent to 110 credits. The number consists of 550 hours of theory and 2805 hours of practice. To support the prospects of the insurance industry in Indonesia in the future, the role of insurance experts is needed so that the required professional and skills qualification standards in this globalization era are becoming increasingly important to print professionals in the field of insurance in Indonesia. The Board of Management of the Insurance Management Experts Association of Indonesia (AAMAI) has determined that Certified Life Insurance (CLI) and Certified General Insurance (CGI) as a requirement to be able to take the exam in AAMAI Profession Professional Certification Institute (LSPP). By having CLI and CGI, the examinees are deemed competent and have basic knowledge of insurance and are entitled to follow Professional Proficiency Exam at LSPP AAMAI. In the curriculum of this Study Program has been given the competencies so that students can pass for this certificate.

In addition, students are also given advanced competencies that are prepared to obtain certificate of Insurance Expert Insurance, both life and general. In this curriculum also given the knowledge-knowledge to take the exam from Persatuan Aktuaris Indonesia (PAI), which is the subject of financial mathematics, accountancy, and statistical probability so that the student is 
expected to obtain Certified Non Life Analyzes (CNLA). The following figure showe the percentage of apprentice work in type of insurance.

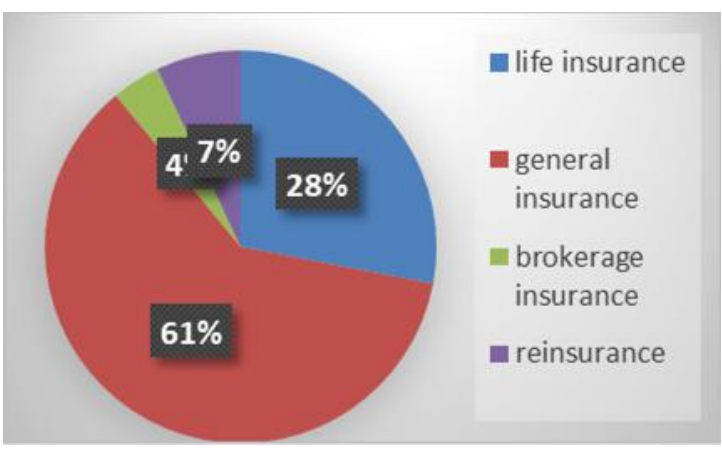

Figure 3. The percentage of Respondent Based on Their Insurance as Apprentices Industry

General insurance has the most student of this study program apprenticed. They chose their insurance industry themselves and the company could interviewed them whether they deserved to be accepted or not. Scientifically, the calculation of life insurance premiums is more complicated than in general insurance. But in fact many students are choosing internships in the life insurance industry.

Basically what students should learn at work place are hard skill, soft skill, employability skill, and life skill. The perceptions of apprentices when they were asked from whom their skill got improved at apprenticeship. Below is the figure 2. Which showed the percentages of what skill they have got in their work place.

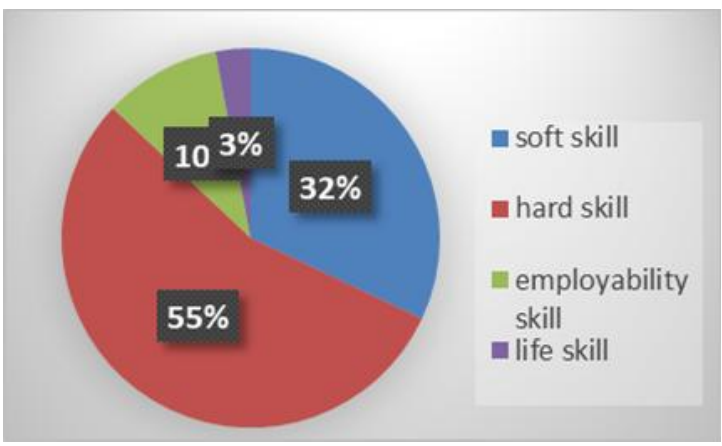

Figure 4. The percentage of Apprentices Response Based on Their Perspectives on Skill

It showed that $86,8 \%$ apprentices can improve their skill by learning from supervisors or tradespersons at workplace. Some apprentices told that they were learning through observing the tradesperson and practicing themselves after that. Through the data, not all apprentices were given attention or command what to do. That made them just pay attention to tradepersons or others working, then execute the job by their own. They also need time to try things out or try and error without always being watched by other workers or supervisors. Sufficient time and lack of pressure made it easier to learn. That means the role of observation in learning skills requires a better understanding. Other stories tell that they liked to either ask or discuss about the job with supervisors. While the remaining percentage presents they obtained from lecturers and appreciated the opportunity to learn from lecturers who are the important role at college who had a lot of time to watch what they were doing compared to tradespersons at work.

Another answers of question when they were asked about the difficulties they experienced in apprenticeship shows 58,5\% from total apprentices had difficulty when they are doing their job which be caused by what they had to do have not been learnt in college yet. This is more likely 
related to $30,7 \%$ of apprentices who said that five semesters they learnt a lot of theory at college such as the theory of underwriting, claim, and actuary science and it did not help much. This occurence is not correlated to the GPAs of apprentices. The students with high GPAs still experienced the difficulty on doing their work task given from supervisors. On the other hand, there was $69,3 \%$ of them said the theory which has been taught is very helpful. To overcome the difficult work task, $47,2 \%$ of apprentices prefered to discuss with trade people and the remaining, $52,8 \%$ chose to learn independently on their own while observe tradespersons.

Additional investigation, there was dissatisfaction from the supervisor with the contribution of the college to apprentice training and honestly said the college just provides a basic beginning and does not really cover their industrial needs. Moreover, the supervisors pointed out that the apprentices were more reluctantly shy to either ask or communicate. The apprentices seemed to be very passive and just waiting to be commanded. This looks a contradiction with the statement from an apprentice who were not given attention or command what to do but this student apprentice at different insurance corporate.

About the curriculum relevance, the educational structures and the curriculum seem to be based on the ideas that vocational knowledge is a sum of different academic and vocational subjects, and consists of the ability to apply general knowledge in specific situations (Hiim, 2017). In insurance administration and actuary, a curriculum is made by the lecturers and insurance practitioners based on skill that met insurance industrial needs in which practical work is the base, and subjects are integrated with practical work experience. It consists of 3 kinds of competencies namely underwriting, claim, and actuary which be developed in separating the theoretical and practical work. The students are suffeciently equipped with the theory of those competencies before they apprentice.

\section{CONCLUTION}

This article is to describe apprentices perception about the suffiency of knowledge provision at Insurance administration and Actuary Study Program shows more than 50\% of them think that this institution has given a helpful theory for the practical learning at workplace. The role of teachers are also very important. The other finding revealed that they prefered to learn by watching others working. They watched, learnt, and did the job. Eventhough, they've experienced difficulty on doing work task because what they had to do was not supported by the theory at college, they could overcome it by discussing with supervisors.

\section{REFERENCES}

Putra, A., Syarifuddin, H., \& Zulfah, Z. (2018). Validitas Lembar Kerja Peserta Didik Berbasis Penemuan Terbimbing dalam Upaya Meningkatkan Pemahaman Konsep dan Kemampuan Penalaran Matematis. Edumatika : Jurnal Riset Pendidikan Matematika, 1(2), 56-62. doi:10.32939/ejrpm.v1i2.302

Billett, S. (2001). Learning in the Workplace: Strategies for Effective Practice. Crows Nest. NSW: Allen \& Unwin.

Chan, S. (2013). Learning through Apprenticeship: Belonging to the Workplace, Becoming and Being. Vocations and Learning: Studies in Vocational and Professional Education, 6(3), 367-383. doi:10.1007/s12186-013-9100-x.

Chan, S. (2015). The Contribution Observation to Apprentices Learning. Journal of Vocational Education and Training, 67(4) (July). 
Collins, A., Brown, J. S. \& Newman, S. E. (1989). Cognitive Apprenticeship: Teaching the Crafts of Reading, Writing And Mathematics, in L. B. Resnick (Ed.) Knowing, Learning and Instruction: Essays in Honour of Robert Glaser. Hillsdale: Erlbaum \& Associates.

Gessler, M., \& Howe, F. (2015). From the Reality of Work to Grounded Work-Based Vocational Education and Training. International Journal for Research in Vocational Education and Training , 2(3), 214-238. doi: 10.13152/IJRVET.2.3.6.

Hiim, Hilde. (2017). Ensuring Curriculum Relevance in Vocational Education and Training: Epistemological Perspectives in a Curriculum Research Project. International Journal for Research in Vocational Education and Training (IJRVET), 4(1) (April).

Ilgen, D. R., Fisher, C. D. \& Taylor, M. S. (1979). Consequences of individual feedback and behaviour in organisations, Journal of Applied Psychology, 6(4), 349-371.

Lave, J. (1990) The culture of acquisition and the practice of understanding, in J. W. Stigler, R. A. Shweder \& G. Herdt (Eds) Cultural Psychology. Cambridge: Cambridge University Press. 